\title{
STEPWISE ANALYSIS OF GASIFICATION REACTIONS WITH ASPEN PLUS AND CPFD
}

\author{
M.S. EIKELAND \& R.K. THAPA \\ Institute for Process, Energy and Environmental Technology, University College of Southeast Norway, Norway.
}

\begin{abstract}
The energy from biomass can be utilized through the thermochemical conversion processes of pyrolysis and gasification. Biomass such as wood chips is heated in a gasification reactor to produce a synthesis gas containing $\mathrm{CO}, \mathrm{H}_{2}$ and $\mathrm{CH}_{4}$. The gas can be further processed to bioproducts or fuels. The thermochemical process involves devolatilization of wood followed by steam gasification, $\mathrm{CO}_{2}$ gasification, methanation, water gas shift reactions and methane reforming. To optimize the performance of the reactor, it is important to study each of the reactions separately.

The reactions are simulated individually using the chemical process optimization software Aspen Plus. The results are compared with simulations performed with the Computational Particle Fluid Dynamic (CPFD) software Barracuda VR 15. The CPFD methodology solves the fluid and particle equations in three dimensions with the transient flow and is time-consuming. Aspen Plus is one dimensional and solves the included reactions fast.

The results of the Aspen Plus and CPFD simulations, given as product gas compositions $\left(\mathrm{CO}, \mathrm{CO}_{2}\right.$, $\mathrm{CH}_{4}$ and $\mathrm{H}_{2}$ ), show that each reaction contributes to the product gas composition differently. Comparison between Aspen Plus and CPFD simulations of individual gasification reactions show good agreement. However, when all reactions are included in the simulations, there is a deviation in the volume fraction of product gas composition.

Keywords: Aspen Plus, biomass gasification reactor, CPFD, dual fluidized bed, reaction kinetics, steam gasification.
\end{abstract}

\section{INTRODUCTION}

Biomass is an attractive source of energy. It is possible to utilize the energy through the thermo-chemical conversion processes of pyrolysis and gasification.

There are different types of reactors used for gasification. Fluidized bed reactors are the most popular amongst them because of the high heat and mass transfer rates that result in high rate of produced gas. The fluidized bed is filled with granular solids called bed materials, which are kept in a fluidized state with a gasifying medium [1]. The principle of dual fluidized bed gasification system is shown in Fig. $1[2,3]$. The reactor is divided into two separate parts - combustion and gasification. The bed material is heated in the combustion reactor and circulated to the gasification reactor. The hot bed materials supply necessary heat for the endothermic gasification reaction. The biomass fed to the gasification reactor is mixed with hot bed materials and gasification agents. The biomass in the reactor is dried and devolatilized to produce volatile gases and solid char particles. The char particles react with the gasifying medium to produce a mixture of combustible gases in addition to some $\mathrm{CO}_{2}$ and water vapor.

To increase the performance of the gasification reactor, it is necessary to study the thermochemical process and its operating parameters. Experimental study of the thermochemical behavior has been difficult due to high operating temperature in addition to time consumption and material costs related to the requirements of constructing hot models and pilot plants [4]. The possibility to study the performance of the reactor by using simulation tools like CPFD and Aspen Plus is valuable for a better understanding of the gasification process. A validated 


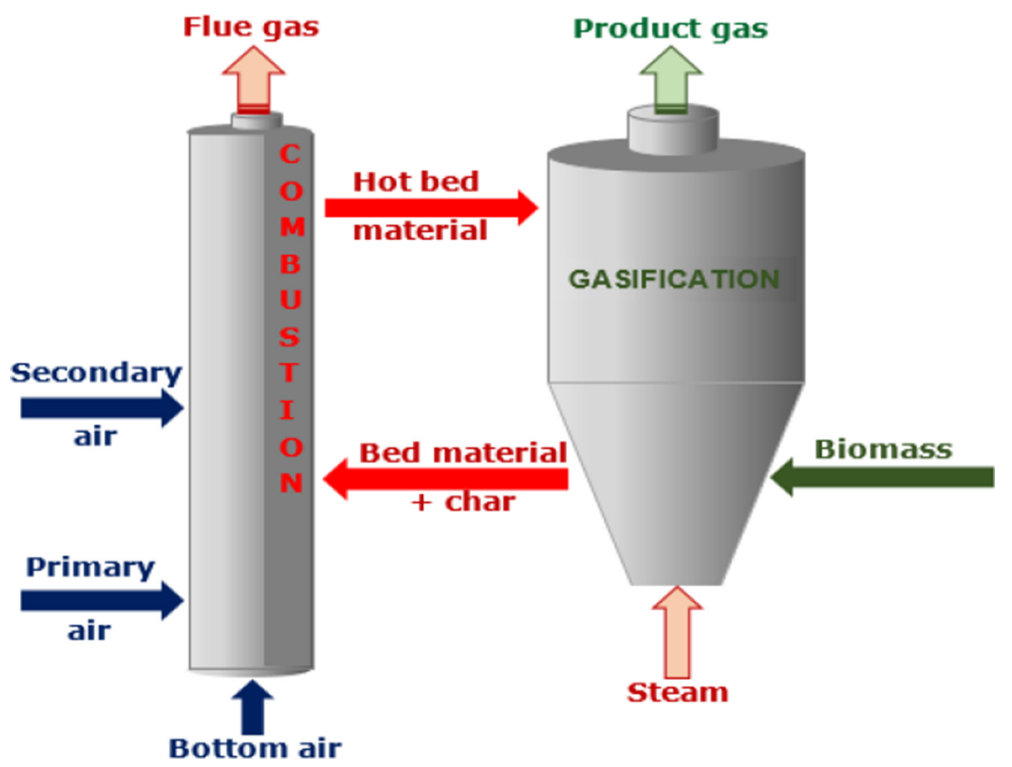

Figure 1: Principle of dual fluidized bed gasification reaction.

computational model could give an approximate answer to many factors affecting the efficiency of the plant.

\section{GASIFICATION REACTIONS}

In a gasification reactor physical, chemical and thermal processes may occur incrementally or simultaneously depending on the reactor design and the feedstock material [5]. First, the biomass is dried and devolatilized. The process is endothermic. The hot bed materials supply all necessary heat for the process. In the devolatilization process, char and volatiles are formed. Depending on the types of feedstock, the volatiles includes $\mathrm{H}_{2} \mathrm{O}, \mathrm{H}_{2}, \mathrm{~N}_{2}, \mathrm{O}_{2}, \mathrm{CO}_{2}$, $\mathrm{CO}, \mathrm{CH}_{4}, \mathrm{H}_{2} \mathrm{~S}, \mathrm{NH}_{3}, \mathrm{C}_{2} \mathrm{H}_{6}$ and very low levels of unsaturated hydrocarbons like acetylenes, olefins, aromatics and tars [1]. Char formed after the devolatilization has a higher carbon concentration than the dry feedstock fed to the reactor. The char is converted to gases by using steam as gasification agent. Depending on the types, the biomass is variable in content and elemental analysis is used to define them. Table 1 shows the ultimate analysis of birch wood.

The ash content (composition of elements such as potassium, calcium, sodium, silicon and magnesium) in wood is less than $1 \%$ [7]. The nitrogen content in wood is also very small. For the simplicity of modeling, all these minor components including $\mathrm{H}_{2} \mathrm{~S}, \mathrm{NH}_{3}$ are neglected. Then the process of devolatilization of wood can be modeled as shown in eqn (1). Material and energy balance can be performed based on the element analysis to set up the stoichiometric equation.

$$
\mathrm{C}_{x} \mathrm{H}_{y} \mathrm{O}_{z}=a \mathrm{CH}_{4}+b \mathrm{CO}+d \mathrm{CO}_{2}+e \mathrm{H}_{2}+f \mathrm{C}_{x} \mathrm{H}_{y}+g \mathrm{C}+h \mathrm{H}_{2} \mathrm{O}
$$

The kinetics of devolatilization is assumed as given by eqn (2). 
Table 1: Elemental analysis of wood [6].

\begin{tabular}{ll}
\hline Elements & Wt.\% \\
\hline Carbon, C & 48.6 \\
Hydrogen, H & 5.6 \\
Oxygen, O & 45.6 \\
Nitrogen, N & 0.2 \\
\hline
\end{tabular}

$$
r_{0}=264000 m_{s} \theta_{f} \exp \left(\frac{-12629}{T}\right)
$$

where the $T[K]$ denotes the temperature. $\theta_{\mathrm{f}}$ is the volume fraction of fluidizing agent and $\mathrm{m}_{\mathrm{s}}$ $\left[\mathrm{kg} / \mathrm{m}^{3}\right]$ is the solid mass of fixed carbon per volume [8]. In this work, the following assumption is made:

$$
m_{s}=\mathrm{M}_{\mathrm{wC}} * C(s)
$$

where $\mathrm{M}_{\mathrm{wC}}$ is the molecular weight of carbon [kg/kmole], and $\mathrm{C}(\mathrm{s})$ is molar concentration of solid carbon $\left[\mathrm{kmole} / \mathrm{m}^{3}\right]$. There are many chemical reactions taking place in a gasification reactor. For simplification, it is assumed that a set of reactions describe the major conversion rates in the reactor [8]. The most common gas-solid reactions in the gasification zone are steam gasification, carbon dioxide gasification, methanation reaction and the gas-gas phase homogeneous reactions are the water-gas shift and the methane reforming reactions as presented in Table 2. The reaction of char particles with fluidizing steam is the major process of char conversion. The char particles also react with the $\mathrm{CO}_{2}$ and $\mathrm{H}_{2}$ gases, which are produced during devolatilization of the wood. Char yield and char reactivity are important in determining the capacity of the gasification reactor [6]. Minimum residual char production and maximum reactivity of char make the reactor more efficient.

Table 3 shows the heats of the major conversion reactions in the gasifier [9]. The methane-reforming reaction is highly endothermic. Also, the reactions with steam gasification and carbon dioxide gasification are endothermic, while the methanation and the water gas shift reactions are exothermic.

\section{MODEL DESCRIPTION}

The aim of this work is to study the thermochemical process in the gasification reactor using simulation tool Aspen Plus and compare the results with the CPFD simulations. Using the reaction rates defined in Table 2, a series of simulations have been performed for the individual reactions occurring in the gasification reactor. The simulations have been carried out to study their contribution to the whole biomass steam gasification process.

\subsection{Aspen plus}

The stream class used in Aspen Plus is MIXCINC and the property method used is RedlichKwong-Soave (RKS) cubic equation of state with Boston-Mathias alpha function (RKS-BM). 
Table 2: Reaction kinetics for the conversion rates in a gasifier reactor $[8,10]$.

Reactions

Steam gasification:

$\mathrm{C}(\mathrm{s})+\mathrm{H}_{2} \mathrm{O} \rightarrow \mathrm{CO}+\mathrm{H}_{2}$

$\mathrm{CO}+\mathrm{H}_{2} \rightarrow \mathrm{C}(\mathrm{s})+\mathrm{H}_{2}$

Carbon dioxide gasification:

$\mathrm{C}(\mathrm{s})+\mathrm{CO}_{2} \rightarrow 2 \mathrm{CO}$

$2 \mathrm{CO} \rightarrow \mathrm{C}(\mathrm{s})+\mathrm{CO}_{2}$

Methanation:

$0,5 \mathrm{C}(\mathrm{s})+\mathrm{H}_{2} \rightarrow 0,5 \mathrm{CH}_{4}$

$0,5 \mathrm{CH}_{4} \rightarrow 0,5 \mathrm{C}(\mathrm{s})+\mathrm{H}_{2}$

Water gas shift reaction:

$\mathrm{CO}+\mathrm{H}_{2} \mathrm{O} \rightarrow \mathrm{CO}_{2}+\mathrm{H}_{2}$

$\mathrm{CO}_{2}+\mathrm{H}_{2} \rightarrow \mathrm{CO}+\mathrm{H}_{2} \mathrm{O}$

Methane-reforming:

$\mathrm{CH}_{4}+\mathrm{H}_{2} \mathrm{O} \rightarrow \mathrm{CO}+3 \mathrm{H}_{2}$

$\mathrm{CO}+3 \mathrm{H}_{2} \rightarrow \mathrm{CH}_{4}+\mathrm{H}_{2} \mathrm{O}$
Reaction rates

$$
\begin{gathered}
r=1.272 * m_{s} * T * \exp \left(\frac{-22645}{T}\right)\left[H_{2} O\right] \\
r=1.044 * 10^{-4} * m_{s} * T^{2} * \exp \left(\frac{-6319}{T}-17.29\right)\left[H_{2}\right][C O]
\end{gathered}
$$

$$
\begin{gathered}
r=1.272 * m_{s} * T^{*} \exp \left(\frac{-22645}{T}\right)\left[C O_{2}\right] \\
r=1.044 * 10^{-4} * m_{s} * T^{2} * \exp \left(\frac{-2363}{T}-20.92\right)[C O]^{2}
\end{gathered}
$$

$$
\begin{aligned}
& r=1.368 * 10^{-3} * m_{s} * T * \exp \left(\frac{-8078}{T}-7.087\right)\left[H_{2}\right] \\
& r=0.151 * m_{s} * T^{0,5 *} \exp \left(\frac{-13578}{T}-0.372\right)\left[\mathrm{CH}_{4}\right]^{0,5}
\end{aligned}
$$

$$
\begin{aligned}
& r=7.68 * 10^{10} * T^{*} \exp \left(\frac{-36640}{T}\right)[C O]^{0,5}\left[\mathrm{H}_{2} \mathrm{O}\right] \\
& r=6.4 * 10^{9} * T^{*} \exp \left(\frac{-39260}{T}\right)\left[\mathrm{H}_{2}\right]^{0,5}\left[\mathrm{CO}_{2}\right]
\end{aligned}
$$

$$
\begin{gathered}
r=3.1005 * \exp \left(\frac{-15000}{T}\right)\left[\mathrm{CH}_{4}\right]\left[\mathrm{H}_{2} \mathrm{O}\right] \\
r=3.556 * 10^{-3} * T * \exp \left(\frac{-15000}{T}\right)[\mathrm{CO}]\left[\mathrm{H}_{2}\right]^{2}
\end{gathered}
$$

Table 3: Heats of reaction for the conversion rates in a gasifier reactor [9].

$\Delta \mathrm{H}^{\circ} 800^{\circ} \mathrm{C}[\mathrm{kJ} / \mathrm{mol}]$

Steam gasification:

$\mathrm{C}(\mathrm{s})+\mathrm{H}_{2} \mathrm{O} \rightarrow \mathrm{CO}+\mathrm{H}_{2}$

136

Carbon dioxide gasification:

$\mathrm{C}(\mathrm{s})+\mathrm{CO}_{2} \rightarrow 2 \mathrm{CO}$

173

Methanation:

$\mathrm{C}(\mathrm{s})+2 \mathrm{H}_{2} \rightarrow \mathrm{CH}_{4}$

$-87$

Water gas shift reaction:

$\mathrm{CO}+\mathrm{H}_{2} \mathrm{O} \rightarrow \mathrm{CO}_{2}+\mathrm{H}_{2}$

$-37$

Methane-reforming

$\mathrm{CH} 4+\mathrm{H}_{2} \mathrm{O} \rightarrow \mathrm{CO}+3 \mathrm{H}_{2}$

228 
The following assumptions were made for the Aspen simulation:

- The system is isothermal and operates under steady state conditions.

- Operations at atmospheric pressure and pressure drops are neglected.

- Nitrogen, sulphur, chlorine and ash are neglected.

- Tar formation is not considered.

- Char is $100 \%$ carbon.

- Heat loss from the gasifier is neglected.

The Aspen Plus flow sheet used in the simulation is presented in Fig. 2. The feed stream, temperature and pressures are defined as described in Table 4. The feed and steam is directed to a yield reactor where the biomass is volatilized to the gas components $\mathrm{CO}$, $\mathrm{CO}_{2}, \mathrm{H}_{2} \mathrm{CH}_{4}$ and $\mathrm{H}_{2} \mathrm{O}$. The residue is considered as solid carbon. The flow from the yield reactor is directed into a Continues Stirred Tank Reactor (CSTR) where the gasification reactions take place. The residence time, reaction stoichiometry and their corresponding reaction rates, given in Table 2, are defined in the reactor setup. After the reactor, water is removed to determine the gas composition on a dry basis. Chemical reactions are expressed by stoichiometric equations and reaction rates are described in terms of a power law format. The rate coefficients based on Arrhenius law are empirically fitted with measured data [8].

The reaction sequences involved in the separate simulations are presented in Table 5. The sequences are used as reaction numbers $1,2,3,4,5,6$ and 7 for the description of the simulations. The reactions are simulated individually using Aspen Plus.

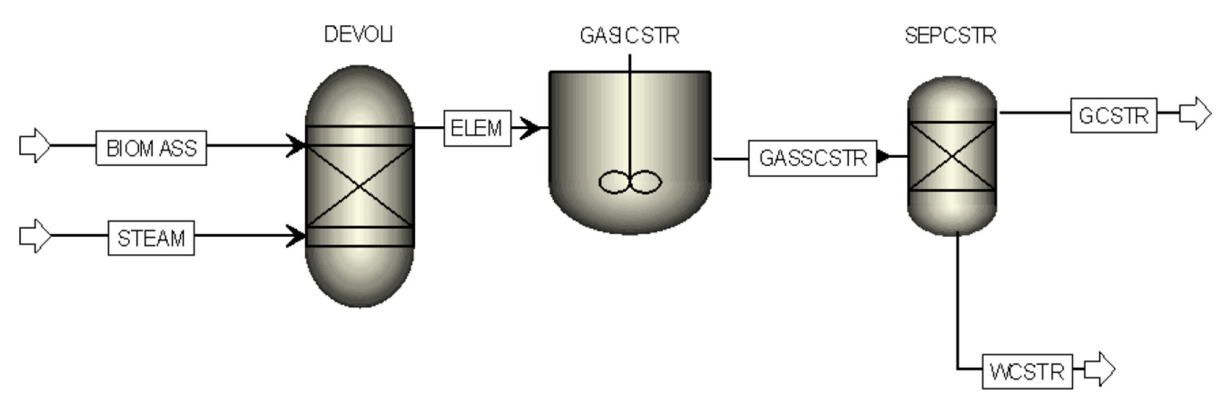

Figure 2: The Aspen Plus process flow sheet.

Table 4: Parameters used in the simulations.

\begin{tabular}{|c|c|c|c|c|c|}
\hline Parameter & Unit & Value & Parameter & Unit & Value \\
\hline Bottom steam feed rate & $\mathrm{kg} / \mathrm{h}$ & 112 & Biomass feed rate & $\mathrm{kg} / \mathrm{h}$ & 112 \\
\hline Steam feed temperature & $\mathrm{K}$ & 1,073 & Biomass inlet temperature & $\mathrm{K}$ & 400 \\
\hline Reaction temperature & K & $1,100-1,130$ & Bed material inlet temperature & K & 1,150 \\
\hline
\end{tabular}


Table 5: Reaction sequences involved in the simulations

\begin{tabular}{ll}
\hline SN & \multicolumn{1}{c}{ Reactions } \\
\hline 1 & Volatilization \\
2 & Volatilization + Steam gasification \\
3 & Volatilization $+\mathrm{CO}_{2}$ gasification \\
4 & Volatilization + Methanation \\
5 & Volatilization + Water gas shift reaction \\
6 & Volatilization + Methane reforming \\
7 & Total reactions \\
\hline
\end{tabular}

\subsection{CPFD}

Computational Particle Fluid Dynamic (CPFD) model is used to simulate the gas-solid flow with heat transfer and chemical reactions. The CPFD numerical methodology incorporates multi-phase-particle-in-cell (MP-PIC) method [11, 12]. The gas phase is solved using Eulerian grid, and the particles are modeled as Lagrangian computational particles. Gas and particle momentum equations are solved in three dimensions. The fluid is described by the Navier-Stokes equation with strong coupling to the discrete particles. The particle momentum follows the MP-PIC description which is a Lagrangian description of particle motions described by ordinary differential equations coupling with the fluid [13].

In the CPFD numerical method, actual particles are grouped into computational particles, each containing a number of particles with identical densities, volume and velocities located at a specific position. The computational particle is a numerical approximation similar to the numerical control volume where a spatial region has a single property for the fluid. With these computational particles, large commercial systems containing billions of particles can be simulated using millions of computational particles [14].

The chemistry in the CPFD model is specified as mass action kinetics. The chemical reactions are described by stoichiometric equations including the corresponding reaction kinetics. The reaction kinetics is expressed as:

$$
k=A_{0} m_{p}^{c_{1}} T^{c 2} \exp \left(-\frac{E}{R T}+E_{0}\right)
$$

where $A_{0}$ is the pre-exponential factor, $E$ is activation energy, $E_{0}$ is activation energy constant, $R$ is universal gas constant, $c$ is a constant. $T$ is the temperature of a particle gas film. The film temperature is an average of the particle temperature and the bulk gas temperature. The particle concentration is given by mass per volume and $m_{p}=\rho_{p} \varepsilon_{p}$, where $\mathrm{r}_{\mathrm{p}}$ is particle density and $\varepsilon_{p}$ is particle volume fraction.

More details about the questions, their parameters and numerical procedures for solving the equations can be found in $[13,15]$. CPFD method solves gasification reactions giving a reasonable prediction. However, the solving the transient flow with chemical reaction takes a significant amount of computational time. It is the reason for trying to simulate the gasification reactions using Aspen Plus, which solves the reactions in one dimension within a short time. 


\section{RESULTS AND DISCUSSION}

The initial step of the simulation is volatilization of biomass, which is the preliminary step for the rest of the global reactions. For the volatilization, the composition out of the Aspen Plus yield reactor is manipulated to be the same as for the CPFD simulations.

Each of the reactions are simulated for the identical operating conditions and parameters. The simulations were run with a residence time of $300 \mathrm{~s}$. The mole percentage of product gases is monitored during the simulation. The results of the simulation from Aspen Plus are compared with the simulation results from CPFD. The results of product gas compositions from the reaction sequences 4,5 and 6 show approximately same compositions of $\mathrm{H}_{2} \mathrm{O}, \mathrm{H}_{2}$, $\mathrm{CO}_{2}, \mathrm{CO}$ and $\mathrm{CH}_{4}$. The results from the reaction sequences 2 and 3 show minor deviations. The reason is that different kinetic models are used in the simulations. The result from the reaction sequence 7 presented in Fig. 3 shows significant variation in the gas composition. The reaction sequence includes all the major reaction used in the model.

In Fig. 3, the $\mathrm{CO}$ mole fraction from Aspen Plus simulation result is about $0.6 \%$ compared to $16.4 \%$ in CPFD simulation. The $\mathrm{CO}_{2}$ and $\mathrm{H}_{2}$ mole fractions are $26.5 \%$ and $33.1 \%$ higher in Aspen Plus compared to the CPFD results. The water concentration has decreased indicating that water is consumed to oxidize $\mathrm{CO}$ to $\mathrm{CO}_{2}$ and $\mathrm{H}_{2}$ as described by the water gas shift reaction.

The results of the simulation for reaction sequence 7 are used to calculate the product gas volume percent on dry basis. The results are compared with the results of CPFD simulation as well as the typical composition of the produced gas from the biomass gasification plant in Güssing, Austria [16]. The results are shown in Fig. 4.

The results from the gasification plant are based on wood chips. The results show a reasonable agreement between the CPDF simulation data and the plant data. However, the results from the Aspen Plus simulation show deviation from the plant and CPFD simulation results. There may be several reasons for these deviations. Further simulations are performed in Aspen Plus to investigate the reasons.

\subsection{Temperature}

Variation of temperature in the gasification reactors will influence on the composition of the produced gas [17]. Fig. 5 shows the composition of the gas as a function of temperature in the reactor.

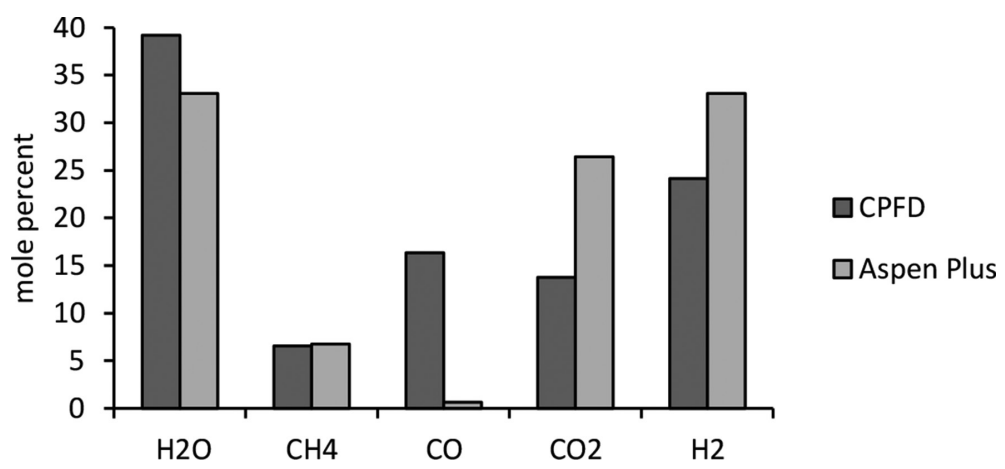

Figure 3: Mole percentage of gas composition for total reactions. 


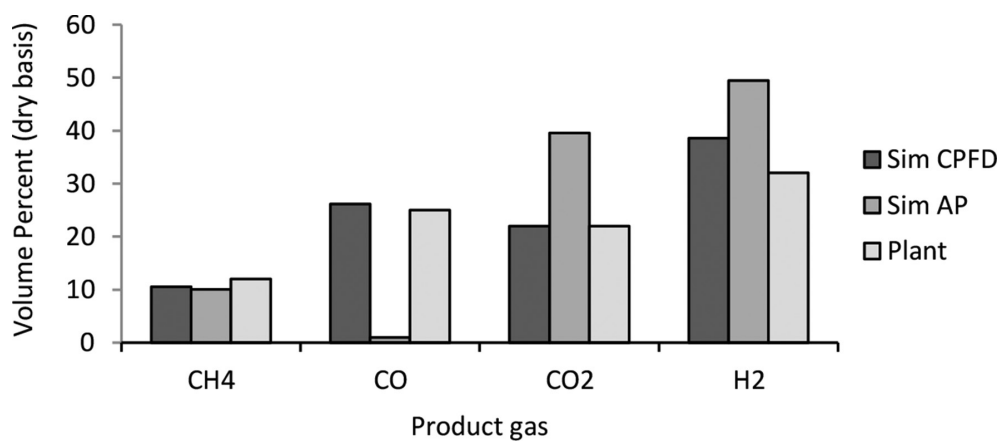

Figure 4: Comparison of gas volume fraction of simulation with plant data.

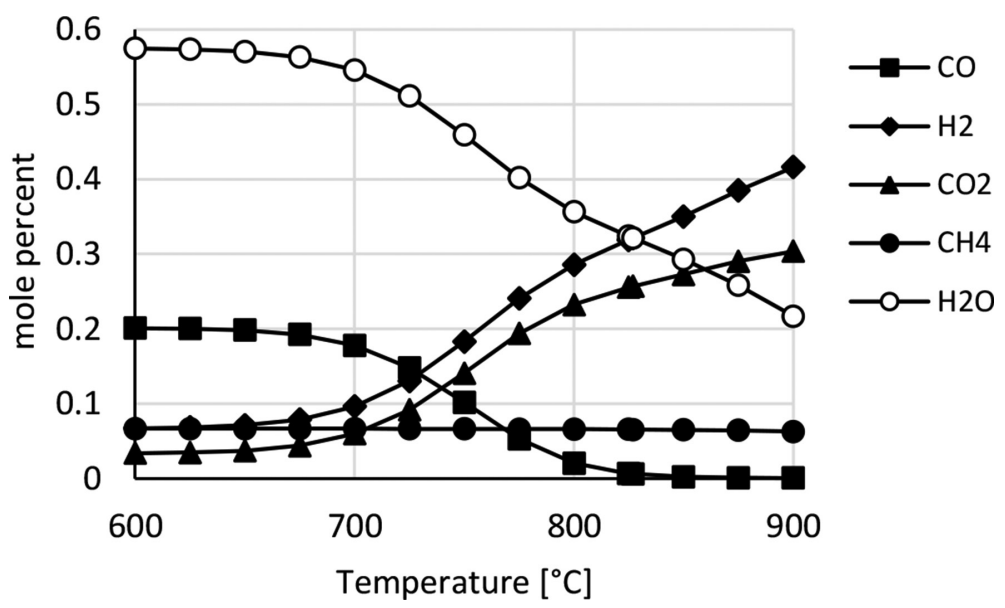

Figure 5: Temperature $\left({ }^{\circ} \mathrm{C}\right)$ as a function of mole percentage of $\mathrm{CH}_{4}, \mathrm{CO}, \mathrm{CO}_{2}, \mathrm{H}_{2}$ and $\mathrm{H}_{2} \mathrm{O}$ simulated by Aspen Plus. Residence time 300 s.

The $\mathrm{CO}$ and $\mathrm{H}_{2} \mathrm{O}$ concentrations decrease when the temperature increases. $\mathrm{CO}_{2}$ and $\mathrm{H}_{2}$ increase with increasing temperatures. The change in composition is highest in the temperature interval of $700^{\circ} \mathrm{C}-800^{\circ} \mathrm{C}$. The differences in temperature profiles can be explained in terms of thermodynamics and kinetics. A temperature increase will favor the endothermic reactions. The steam gasification, the $\mathrm{CO}_{2}$ gasification and the methane reforming reactions, have a positive heat of reaction and, are endothermic. These three reaction sets favor a production of $\mathrm{CO}$ and $\mathrm{H}_{2}$ and consumption of methane. The methanation and the water gas shift reactions are exothermic. Increasing the temperature for these reactions will make the heat content of the system to increase. The system will then consume some of that heat by shifting the equilibrium to the left as described by Le Chateliers principle. This will lead to a reduction of the $\mathrm{CO}_{2}$ and $\mathrm{CH}_{4}$ concentrations. However, by implementing the reaction rates, the temperature will contribute to the reactions in a different extent. All the reaction rates are dependent on the temperature. An increase in temperature gives a decrease in the exponential factor of the reaction rate expression. The water gas shift reaction has the dominating reaction rate and the highest reaction constant, implying a consumption of $\mathrm{CO}$ and water vapor, and 
production of $\mathrm{CO}_{2}$ and $\mathrm{H}_{2}$. The inflection point for all the reaction sets are typical at around $600^{\circ} \mathrm{C}-700^{\circ} \mathrm{C}$ and is the reasons for the steep increase/decrease in concentrations around this point. Aspen plus simulates with a uniform temperature distribution within the reactor, while CPFD gives a temperature distribution within the reactor.

\subsection{Residence time}

Residence time or reactor volume will influence the composition of produced gas from the gasifier. A longer residence time will give the reactions more time to reach equilibrium. To increase the residence time, it is necessary either to increase the reactor volume or to reduce the feed rates to the reactor. Fig. 6 shows the composition of the produced gas at different residence times.

The residence time is crucial for the produced gas composition. Increased residence gives a higher $\mathrm{H}_{2}$ and $\mathrm{CO}_{2}$ concentration, while $\mathrm{CH}_{4}$ and $\mathrm{CO}$ concentrations decrease with residence time. The residence time used in Aspen Plus is $300 \mathrm{~s}$. However, a residence time of about $13 \mathrm{~s}$ will give a $\mathrm{CO} / \mathrm{H}_{2}$ ratio of $1: 1$. The $\mathrm{CO}$ concentration will then be more comparable to the $\mathrm{CO}$ concentration observed with $\mathrm{CPFD}$. To produce a gas with a satisfying ratio between $\mathrm{CO}$ and $\mathrm{H}_{2}$, an optimized reaction time should be reached.

\subsection{Heating value}

The results of simulation on the total heating value of product gases from Aspen Plus are compared with the results from CPFD. The results are shown in Fig. 7. The product gas heating value during volatilization, methanation, water-gas shift and methane reforming reactions have good agreements with the computational results from CPFD. The $\mathrm{CO}_{2}$ gasification has some deviation. The product gas heating value from the steam gasification reaction deviate significantly between these two computational methods, and this may be the reason for the deviation in product gas heating value on the result of the total reaction.

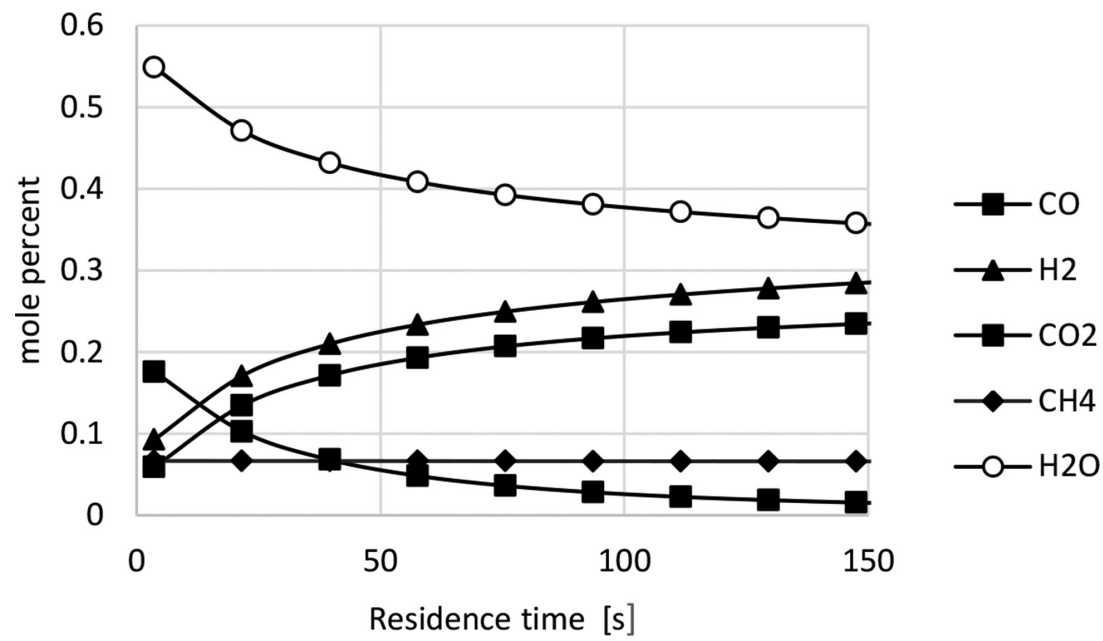

Figure 6: Residence time (s) as a function of mole percentage of $\mathrm{CH}_{4}, \mathrm{CO}, \mathrm{CO}_{2}, \mathrm{H}_{2}$ and $\mathrm{H}_{2} \mathrm{O}$ simulated by Aspen Plus. Temperature 1,100 K. 


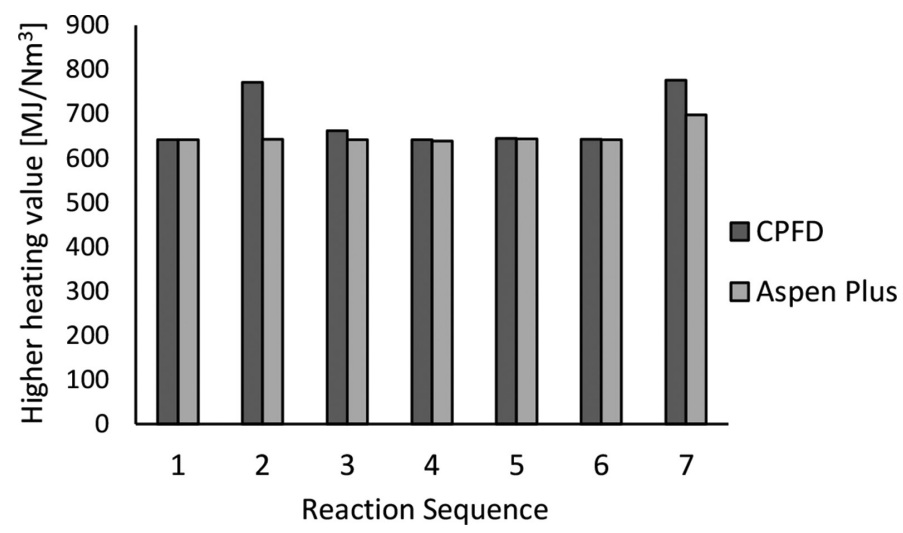

Figure 7: Comparison of computer results of Aspen Plus and CPFD on higher heating values of product gas simulated.

\section{CONCLUSION}

Steam gasification of birch wood is simulated using Aspen Plus. MIXCINC stream class and Redlich-Kwong-Soave cubic equation of state with Boston-Mathias (RKS-BM) alpha function are used as property method. The reactions included in the simulation are steam gasification, carbon dioxide gasification, methanation, methane reforming and water gas shift reactions with their corresponding reaction kinetics. All those reactions are simulated individually as well as together. The results of the simulations are compared with the results of the CPFD computational method that is simulated with similar parameters and conditions.

The results of the product gas volume fractions simulated with methanation, water gas shift reaction and methane reforming have good agreements with CPFD computational method, while the results with steam gasification and $\mathrm{CO}_{2}$ gasification has some deviation. The results of total reaction show significant deviation between the two computational methods. The produced gas composition depends on the temperature. A higher temperature reduces the $\mathrm{CO}$ concentration, but increases the $\mathrm{H}_{2}$ and $\mathrm{CO}_{2}$ concentrations. A long residence time give a severe decrease of the $\mathrm{CO}$ concentration. The residence time have to be optimized to obtain a satisfying $\mathrm{CO} / \mathrm{H}_{2}$ ratio. The two computational methods give about the same total higher heating values.

\section{REFERENCES}

[1] Basu, P., Biomass Gasification Pyrolysis and Torrefaction. Practical Design and Theory, 2nd edn., USA: Academic Press, 2013.

[2] Bolhar-Nordenkampf, M. \& H. Hofbauer. Gasification Demonstration Plant in Austria. In IV. International Slovak Biomass Forum, Bratislava, 2004.

[3] Hofbauer, H., Rauch, R. \& Bosch, K., Biomass CHP plant gussing - a success story. In Expert Meeting on Pyrolysis and Gasification of Biomass and Waste, Strasbourg, France, 2002.

[4] Thapa, R.K. \& B.M. Halvorsen, eds. Stepwise Analysis of Reactions and Reacting Flow in a Dual Fluidized Bed Gasification Reactor WIT Transactions on Engineering Sciences ed. Advances in Fluid Mechanics X. WIT Press: London, 82, 2014.

[5] Rezaiyan, J. \& Cheremisinoff, N.P., Gasification Technologies, A Primer for Engineers and Scientists. CRC Press Taylor \& Francis Group, 2005. 
[6] Zanzi, R., Sjostrom, K. \& Bjornbom, E., Rapid pyrolysis of agricultural residues at high temperature. Biomass and Bioenergy, 23(5), pp. 357-366, 2002.

http://dx.doi.org/10.1016/S0961-9534(02)00061-2

[7] Di Blasi, C., Signorelli, G., Di Russo, C. \& Rea, G., Product distribution from pyrolysis of wood and agricultural residues. Industrial \& Engineering Chemistry Research, 38(6), pp. 2216-2224, 1999.

http://dx.doi.org/10.1021/ie980711u

[8] Xie, J., Zhong, W., Jin, B., Shao, Y. \& Huang, Y., Eulerian-Lagrangian method for three-dimensional simulation of fluidized bed coal gasification. Advanced Powder Technology, 24(1), pp. 382-392,2013.

http://dx.doi.org/10.1016/j.apt.2012.09.001

[9] Moulijn J.A., Makkee, M.\& Van, D.A., Chemical Process Technology, John Wiley \& Sons, 2013.

[10] Umeki, K., Yamamoto, K., Namioka, T. \& Yoshikawa, K., High-temperature steamonly gasification of woody biomass. Applied Energy, 87(3), pp. 791-798,2010. http://dx.doi.org/10.1016/j.apenergy.2009.09.035

[11] Andrews, M.J. \& O'Rourke, P.J., The multiphase particle-in-cell (MP-PIC) method for dense particle flow. International Journal of Multiphase Flow, 22(2), pp. 379-402.

[12] Snider, D.M., An incompressible three-dimensional multiphase particle-in-cell model for dense particle flows. Journal of Computational Physics, 170(2), pp. 523-549, 2001. http://dx.doi.org/10.1006/jcph.2001.6747

[13] Snider, D. \& Banerjee, S., Heterogeneous gas chemistry in the CPFD EulerianLagrangian numerical scheme (ozone decomposition). Powder Technology, 199(1), pp. 100-106, 2010.

http://dx.doi.org/10.1016/j.powtec.2009.04.023

[14] Chen, C., Werther, J., Heinrich, S., Qi, H.Y. \& Hartge, E.U., CPFD simulation of circulating fluidized bed risers. Powder Technology, 235(0), pp. 238-247, 2013. http://dx.doi.org/10.1016/j.powtec.2012.10.014

[15] Snider, D.M., Clark, S.M. \& O'Rourke, P.J., Eulerian-Lagrangian method for three-dimensional thermal reacting flow with application to coal gasifiers. Chemical Engineering Science, 66(6), pp. 1285-1295, 2011.

http://dx.doi.org/10.1016/j.ces.2010.12.042

[16] GRE MULTIFUEL GASIFICATION 2014 [cited 2016 04.2016]; Available at: http:// www.gussingrenewable.com.

[17] Eikeland M.S., Thapa R.K. \& Halvorsen B.M., Aspen plus simulation of biomass gasification with known reaction kinetic. In Conference on Simulation and Modelling (SIMS 56), Linköping University Electronic Press: Linköping University, Sweden, pp. 7-9, 2015.

http://dx.doi.org/10.3384/ecp15119149 